\title{
The Nature and Characteristics of the License Agreement and Its Compatibility with Certain Contracts in Civil Law
}

\author{
Gholamreza Afsharipour \\ Department of Law , Payame Noor University(PNU), Tehran , Iran \\ Email: afsharipoorreza@gmail.com
}

\author{
Doi:10.5901/mjss.2016.v7n4s1p105
}

\begin{abstract}
The license is a contract which gives permission (privilege) to apply intellectual property, without transferring any kind of ownership. This permission is not usually given independently, but within other contracts; As Franchising, Buy- Back, and B.O.T. License types are; Exclusive, nonexclusive, voluntary, compulsory and so on. Technical knowledge is also transferred in the licensing agreements. The value of Technical knowledge, lies in its anonymity and confidentiality; so publicizing the technical knowledge violates the validity of the contract. The license is promissory, commitment and often a formal contract. Its nature does not match any of the specific contracts in Iran's civil law. It seems that, the license is an anonymous contract, subject to Article 10 of this law. This article is an attempt to identify licensing agreement. For this purpose, first a definition of the concept is presented and then its position is explained. Then, the most important types of this agreements are briefly explained. Finally, the attributes and nature of this agreement are discussed from the perspective of Iran's rights and comparative law.
\end{abstract}

Keywords: License contracts, technology transfer, industrial property, technical knowledge patent, trademark, the nature of the license contract

\section{Introduction}

There are two general ways to achieve technology; production or purchase. The second method is usually called technology transfer and License contract is one of its most important legal mechanisms. The main reasons of technological purchasing can be summed as; this method requires little or no investment in research and development; rapid utilization is possible, economic and technical risks are low. There are also good reasons for selling technology; return on investment used in research and development of technology, and also the fact that the technology is fully put into operation. Thus, because of the buyers and sellers, technology transfer would be possible. Technology transfer may be done within national boundaries or international borders. In inland areas, technology can be transferred from industry to industry and from one organization to another. International Transfer of technology may be conducted between two developed countries, between two developing countries, or between a developed country and a developing country (Sharif, 1997, p. 8).

If the parties, work together to increase mutual benefit to, the deal will be a continuous interaction. The most common incentives of the license giver are to benefit from greater production capacity, to expand the field of distribution and to use local management experiences of License receiver. Hence, License giver, through License receiver, may penetrate the market more effectively and more easily. License receiver will also benefit from a superior technology that enables him to produce higher quality products and reduce costs (Nanayakkara, 200, p. 13).

The role of foreign investment in the country's economic development is obvious. In this regard, the first article of "Foreign Investment Promotion and Protection Act", passed in 2002, describes patents, technical knowledge, trademarks and specialized services as some of the examples of foreign capital. The second article of this Act, "Technology modernization" is a condition for admission of foreign investment. Considering this matter the importance of technology transfer mechanisms, patents, and other industrial property are being cleared.

It should be recognized that licensing are not usually signed independently, but within other contracts, such as "B.O.T "(build, operate, transfer) or" counter trade" in which licensing or transfer of technical knowledge is also provided. For this reason, after the recognition of License contracts, other contracts involving the License and transfer of knowledge will be introduced as well. Examining the characteristics and nature of the entity (compatibility with certain contracts in civil law of Iran or of Article 10 of the law) will be the main topic of this article. 


\section{Definition of License, its status and types}

\subsection{The definition of license}

Before defining the term, it is first necessary to define it literally. License is originally a French word and in Persian dictionary Dehkhoda it is defied as: "permission; higher degree usually that includes three years of education after high school; the degree of certificate." (Dehkhoda, 1994, p. 1753)

In the Oxford Advanced Dictionary it is also defined as: "to give sombody official permission to do, own, or use something, such as a driver's license or license of office" (Hornby, 2000, p. 740). In the legal literature of our country, many equivalents are attributed for the term License. Some have preferred "permission" (Eshmittof, 1999, pp. 418, 419) and some of them prefer the term "privilege" (Nasiri, 2004, p. 328). In some translations, the franchise is taken an equivalent to the above terms; due to the confusion, the comparison of the translation with the original text is difficult sometimes. The concept of the License isn't so much different from the literal term. In this regard, the legal dictionary "Black" has provided some descriptions that help to clarify the point. In this dictionary, there are detailed explanations under the heading License, which some have little to do with us, but in explaining patent License, the following is stated: "Written permission of the owner or a patent that enables another one to invent a product in a given period of time or territory; A transfer that does not affect the owner's monopoly, Except that prevents him from exercising his right to prohibit. License patents, transmits fewer rights than selling it. The language or any other behavior used by the owner that shows the owner's consent; it is achieved on the basis of inference and constitutes a license" (Campbell, 1990, p. 920). This definition implies that in the License contract, the ownership of the subject of contract is not transferred, but simply the permission to use is transferred. License is defined a book entitled a practical guide to the provisions of competition law in European Union, as: License is a contract between the holder of intellectual property and the other party who wants to get legal permission from the License provider, whether to use the intellectual property in the exclusive domain or to exploit the technological innovations protected by intellectual property's rights. License issues are often recorded In the field of technology and intellectual property [...] Though technical knowledge (unregistered) is associated with the production License" (Curley, 2004, p. 4).

There are a few Persian literature in this field in which some lawyers have offered this definition of License agreement:

"Permission to use or License is a contract under which the owner of a mark, permits a third party to use it in an exchange with s payment called the royalty, so such a contract is a lot like the lease. This contract, on the other hand, can be likened to coexistence treaty (or adjustment of the use of mark) whereby owners of trademarks determine the use of each contract and refrain from conflicts"(Shams, 2003, p. 177). Another in the concept of License contract in our country is the considering of its relation to technology transfer and foreign investment (indirect). Iran, like other developing countries, shows interests in the annual quota's regulations in support of domestic products and industrial units; thus, basically the importation of goods which are similar to the ones produced in Iran is unauthorized or may be authorized with some conditions such as heavy imposed customs duties and commercial benefit that virtually make it impossible to compete with leading producer, and minimize Iran's foreign imports. In such circumstances, foreign manufacturers attempt to provide direct investment in Iran and in fact make their goods in Iran or through lending and technical assistance to Iranian producers try to maintain and develop their sales market in Iran. In this case, a contract entitled a technical assistance contract and royalties is concluded with the Iranian company. According to the agreement, the Iranian industrialists are allowed to use the trademark and patent or technical knowledge of the foreign manufacturer on the payment of royalties. For example, Iranian producer, attempts to produce a TV with foreign brands and technical specifications, and in return, at the time of sale of any part of the TV set, pay a value as royalties to the foreign producer (Nasiri, ibid, pp.297, 298).

\subsection{License status}

We already said that license is formed not independently but within other contracts; so now we want to discuss about some licenses;

\subsubsection{Franchise agreement}

As some authors of the international trade law have said, "franchise" is a formal system for joint enterprise between two independent trader during which one party (the franchiser), receiving a payment (cash or ...) and under certain 
conditions, grants the right to manufacture and sell products as well as the right to use the trademark or brand to the other party (franchisee). Moreover, the franchiser, gives the technical services, technical assistance and knowledge to the other party, and teaches the business practices to him. Franchise contracts are concluded primarily with marketing objectives. (Van Houtt, 2002, p. 213). In this regard, "the United Nations' Industrial Development Organization" believes that the franchising is a way of distribution of goods and services through license and the trademark, also it blends the licenses of technical knowledge, trade secrets, copyright and distribution agreements (UNIDO, 1996, p. 211). So the elements of a franchise contract can be summarized as: permission to use a name or a registered trademark, transfer of technical knowledge on the part of the franchisor to the franchisee and finally, the distribution of finished goods.

Although the underlying franchise contract requires the trademark license and the above agreements are similar in this regard, the franchise agreement, the franchisor's monitoring activities and technical services are very remarkable. This difference has legal effects; in cases where the goods are generally distributed by a franchisee or his activities harm to third parties, the franchisor may be also charged and called the lawsuit (Ibid., P. 210). This, in fact, is what the general rules of civil liability refer to as "the Responsibility resulting from someone else's activity". Therefore it is recommended that the ways of remedies be predicted and mentioned in the contracts accurately.

There are other differences between the franchise contract and trademark license; in the franchise, the royalties are more of a "Management Fee" than the use of the mark; in the license the emphasis is on producing but in franchise marketing purposes are considered as a stage after the production, license is involved in established trademark and businesses while franchise involves new businesses, in trademark licensing most of the improvement in the transfer of production from one party to another is subjected to separate agreements but in franchise the progress is considered to be given to the franchisee as an integral part of the contract without negotiation. (Ibid., P. 212).

\subsubsection{Build, operate, transfer (B.O.T)}

The other type of contract is the build, operate and transfer contracts. These contracts are usually concluded in infrastructure and mother industries; in these contracts the private sector of the recipient governments, has no financial ability or changing them; therefore, the government or state-owned companies are involved usually on one side of these contracts. In a conventional BOT contract, the state permits a consortium of private companies to finance an infrastructure project, implement it and in return of the expenses, use the project for a while and after that transfer it to the state (Shiravi, 2005, p. 10). Absorption of the advanced technical knowledge is one of the intentions of the contract which is achieved through education, obtaining various licenses and transfer of technical knowledge.

In these agreements, the consortium that is responsible of financing and operation of the project is assumed to require multiple licenses to produce goods and services. Using these licenses during the implementation of the project is the responsibility of the consortium, and thereafter the project is transferred to the acceptor state. It must be ensured that licenses are allocated to the projects so that in the time of transfer, the states wouldn't face any difficulties. Remedies must be taken in case that the owner of license, prohibits the consortium from sub-license. In addition to patents' licenses and other registered industrial ownerships, consortium may require to the necessary technical knowledge of its owners to launch a project. This knowledge through training contracts the technical and engineering services, industrial cooperation, and so on is transferred to the consortium and then to the state of receiving capital. (Ibid., Pp. 41-39).

\subsubsection{Buyback contracts}

Another contract which involves a license and a transfer of technology, is buyback. In fact buyback is a counter trade type of contract. In this series of contracts, Issuer undertakes additional and mutual commitments in addition to the common commitments of goods and services 'contracts. (Shiravi, 2004, p. 5).

One of the properties of buyback, compared with "counter purchase," which is another kind of counter trade agreement, is the coherence and relationship between the exported goods and redeem of the exporter. In fact, what is exported and what is purchased are linked in a manufacturing process in a buyback contract. Exporter is committed to the supply of machinery, raw materials, technology, technical knowledge and technical assistance to the importer so that an economic unit is created. When the unit is built, the cost of exported products is compensated through the redemption of the goods produced in "the very economic unit ". (Ibid., Pp. 16, 17).

It seems that in addition to the investment and financing of projects, transfer of technology and technical knowledge is one of the objectives of the contracts and, therefore, so the raw materials (hardware), technical management services (software), patents licensing's rights and other industrial ownerships are recorded as buyback contracts. 
In our country the buyback mechanism is usually used to extract oil and gas deposits or develop them. In the foreign investment law and its regulations, the buyback and BOT contracts are investments in which the return of interests are purely possible through the operation of the projects, and does not rely on state guarantees or banks ${ }^{1}$

\subsection{Some types of license contracts}

Licensing have been divided into different types, including the swap and free license, formal and permission licenses, the exclusive and nonexclusive license, mutual and unilateral license; compulsory and voluntary license (Staines et al., 2002, p. 99) and there are also other types which are hardly necessary to be mentioned. Two types of licensing are is investigated in this article.

\subsubsection{Voluntary and compulsory license}

In some countries, when the owner of a patent, trademark or other registered intellectual property doesn't apply to the use of the property and give others the permission to do so, the competent authority will have the power to register the property and grant the license to any qualified applicant. In this sense, the license contract is divided into voluntary and compulsory. "Voluntary license" is the standard license that has been dealt with in detail in this article. But "compulsory license" needs to be clarified. The history of compulsory license dates back to monopoly legislation of Britain in 1623; in 1803 compulsory license system was known as a part of the patent's right law. The compulsory license is a permission issued by a competent national system and is awarded to the person applying for registration of a product or process without the consent of its owner's use. Compulsory license is an exception to the rules relating to patents. In fact, this is a part of a social order that seeks to strike a balance between the exclusive rights of patent holder on the one hand and consumers' rights on the other hand. (Habiba, 2004, p. 173).

It seems that the philosophy of compulsory license, is the principle of free competition, prohibition of monopoly, achieving public order and the interests of society; a person who disclose the technical knowledge and trade's secrets, and registers them, is committed to operate or permit others to operate and receive the royalties.

According to Article 48: "Patent act" of the United Kingdom passed in 1977, At any time after the expiration of three years, or of such other period as may be prescribed, from the date of the grant of a patent, any person may apply to the comptroller on one or more of the relevant grounds for a license under the patent; for an entry to be made in the register to the effect that licenses under the patent are to be available as of right; or where the applicant is a government department, for the grant to any person specified in the application of a license under the patent (Marret, 1991. P. 112).

According to the Article 74 of the country's industrial property law of Mexico, if three years of the granting of the patent or four years after its application is passed, and the invention is not exploited yet, any beneficiary can request from the State Institute of Industrial Property to grant a compulsory license unless the patent holder have good reason for not using it. Compulsory license' applicant must have the technical and financial capacity of exploitation of the invention. However, the competent authority, before granting a compulsory, license gives the holder reasonable opportunity to exploit the invention otherwise compulsory license will be awarded. After hearing the parties' statements, the State competent authority, decides on the grant of a compulsory license, and conditions the scope of utilization and the royalty payable to the owner. Royalties end by the end of the patent's life. With the demand of the holder or receptor the terms and conditions of a compulsory license may be changed or modified, especially when the owner is issued other licenses in the meantime that have better conditions than compulsory license. Compulsory license cannot be exclusive, i.e. it is possible to also allow other applicants to use the license and the applicants can only grant sub-license with reference to the owner. (Staines, et al, ibid, p. 104).

Article 31 of the trade-Related Aspects of Intellectual Property Rights (TRIPS) detailed conditions for granting compulsory license as: Where the law of a Member allows for other use of the subject matter of a patent without the authorization of the right holder, including use by the government or third parties authorized by the government, the following provisions shall be respected: request applicants to determine royalties, scope and duration of operation, nonexclusiveness, non-assignability, priority of domestic purposes, the possibility of judicial reviews, and revoking the license in the loss of the particular circumstances (Habiba, a priori, p. 176).

\footnotetext{
1 Article 3 of Foreign Investment Promotion and Protection Act. Foreign investments in all sectors within the frameworks of "civil partnership," "buy back," and "build, operate and transfer (BOT)" where the return of principal and profit arises solely through the economic activity of the same investment project and does not rely on any guarantee by the government or banks or government companies.
} 
It should be noted that recently in Article 17 of the "Law on patents, industrial designs and trademarks" of Iran, compulsory license is predicted.

\subsubsection{Exclusive, non-exclusive and sole licenses}

Based on unity or diversity of receiver and territory of the rights License contract can be divided into exclusive, nonexclusive, and sole licenses. These terms are not defined in the laws of many countries and therefore each case should be made clear.

One of the common ways of allowing the use of intellectual property is "non-exclusive License". When the License is non-exclusive, the transfer of rights to the License receiver and others in the geographical territory of the License is possible and the receivers are in a similar position. (Fan Week, 2003, p. 3).

The License, is exclusive when the License recipient is the only person who can take advantage of the rights vested in the territory; for example, License- recipient in the field of distribution of fast foods may obtain the exclusive rights acquired in a specific geographical area. In some cases, the granted rights in the exclusive license are so vast that they cannot be easily distinguished from the sale of intellectual property, for example, some manufacturers of computerized software grant exclusive license in sales and distribution of the product in a manner that the License receiver also can grant sub-License. The contract in this situation is exclusive even for the License holder and he remains modest about intellectual property's rights (ibid., Pp. 4, 5).

Exclusive license may be absolute or conditional. Absolute exclusive license it is not so much different from selling the intellectual property, but often in practice, exclusive licenses are subject to certain constraints. These constraints may be used in the geographical territory of intellectual property or the use of such property; and these properties may be granted to the former contracts; i.e. the right of the former participants is reserved, and also the License holder may protect its own right to use. (Meyer, 2004, p. 8).

Exclusiveness or non-exclusiveness of a License agreement is an important issue in the strategy and planning of License recipient; For example, when the license receptor faces serious barriers to produce a pharmaceutical product, its interest is in obtaining the exclusive license. Also, the company may need exclusive license for several years to acquire a reputation. Usually in Exclusive licenses a minimum royalty is determined regardless of the profitability of the operation of the contract for the license receiver. License receiver is required to provide its utmost efforts to exploit intellectual property of the contract and its negligence, turns the exclusive license to a non-exclusive license. Commitment to use by determining the minimum selling of a currency (i.e. dollars) or the product or an access to certain extent of the development of an exploitation is inserted; it is also possible that the contract merely contain an obligation to use the best or the most reasonable endeavors to develop, distribution or sale of manufactured products. (Ibid., P. 10).

The other term that relates to the above licenses and is usually used alongside exclusive license is the "sole License". The difference between the two terms is stated by an author; this difference concerns the distribution and agency agreements, but it is also applicable to our objectives:

"'If these terms (exclusive and sole) are not defined in the contract, the Modern business practices often attribute to the following meanings:

1. Both the term connotes that the original (in our case the License holder) does not have such a right to determine a distributor or representative (in our case the License receptor) for the territory.

2. If representatives (in our case license) are soles, the original can take the responsibility of the sale in its territory and determine representatives for itself, in fact, if the term 'sole license' is used the License holder can use the intellectual property of the contract.

3. If the agency is exclusive, original is not allowed even to compete with the representatives in the realm of contract. "(Schmitof, ibid, p. 260).

The above interpretation of the definition of the term "exclusive" is confirmed in Article 130 of the British 1977 patent law, "Exclusive license means a License from the proprietor of or applicant for a patent conferring on the licensee or him and persons authorized by him, to exclusion of all other persons [including the proprietor and applicant] any right in respect of the invention to which the patent or application relates ...".

In the exclusive license, even the License holder is prohibited from the operating while it is not the case in sole License. However, it is recommended that 'whether the licensees themselves can be in the territory of contract or not' be stated in the contract. 


\section{The Nature of License contract}

The legal nature of the contract is an important issue that must be taken into consideration in examining any contract. This matter is important in terms of understanding the rules governing the contract. If the nature of the contract is compatible with the predetermined conventions of contracts (certain contracts), the rules governing the credit of those contracts, will also apply the discussed contract; otherwise, only the general conditions and rules must be established and whatever is written in the contracts should be adhered to, in the cases that there is nothing in the contract, the principle would be refraining from any impose on the parties, unless there is a law in this area. Because it helps to determine the terms of a contract to nature, License contracts completed in the first study and then discuss the nature of it. Since determining the terms and characteristics of a contract helps the perception of its nature, in this section we first will study the contracts' characteristics and then discuss their nature.

\subsection{Characteristics of License contract}

\subsubsection{Promissory contract}

This contract purely result in the commitment and legal obligation of one party, such as a contract where one party is committed to build a particular house according to a plan and in return the other party is obliged to pay him. In contrast, the possessory contract as its name suggests, is a contract that transfers ownership of property from one party to the other party. However, this transfer also contains obligation, such as the sale of certain property in the transfer of ownership, in which the seller is obliged to submit the property to the buyer. Iranian Civil Code, has not mentioned the promissory and possessory contracts in the official classification of the contracts, however the effect of possessory and promissory contracts are attributed to the legal action of will in Articles 825 to 826, in Articles 338 in sales contract and in article 466 in rent contract, the possessory effect is given to these contracts. In addition, the definitions of reward, attorney and guarantee contracts presented by the legislation, the promissory contracts can be realized. (Shahid, 2001, pp. 79, 83).

The effects and consequences of promissory contract are not consistent with the provisions of possessory contracts, for example, in the possessory contracts, the traded case must be available during the contract otherwise the transaction is void. But in the promissory contract the transaction may not be available during the contract and be created after it. In addition, the possessory contract grants an objective right for the promisee that is valid against all; the right to pursue is one of its parts, which means that the holder can own property anywhere. (Safai, 2001, p. 40). Now that the possessory and promissory contracts were defined, we want to realize whether the license contract is a possessory contract or a convened one.

Considering the nature of License agreement (intellectual property) and that there are no objective foreign ownership, we put it in the category of promissory contracts. In the case of License agreement, since the technical knowledge, is not registered, it is realized that it is a promissory contract. Nevertheless, the transfer of ownership of the patent or trademark (and other Industrial Properties) may result in the Possessory features of the license agreements; in this case the assignee has the right to pursue directly and without resorting to the transmitter any person who has violated and exploited patent or trademark. In other words, he obtains an objective right on the subject of the contract and this right is the effects of any possessory contract. However, we should note that our discussion is on the right to use (license) Industrial Property, not to transfer them. Although, there isn't much distinction between the transfer of ownership of patent, trademark (and other Industrial Property) and their permission to use.

\subsubsection{Bilateral}

The Iranian right and Imamieh Jurisprudence, from which Iranian civil law is derived, have never mentioned bilateral and promissory. But in Imamieh Jurisprudence, the concept of reciprocal and consideration especially in the sale contract, is stated and has many applications; accordingly, one of the divisions of contracts by the civil right' authors is the division of reciprocal contracts and free contracts. (Emami, 2000, P. 181).

French lawyers have divided the contracts into bilateral and unilateral in other words, the contracts requiring both parties and contracts requiring one party. bilateral contracts in the French law are contracts in which reciprocal obligations are implemented on the parties, such as the sale and lease debt, and in return, unilateral contracts only implement a commitment on one party and the obligee does not take the responsibility of anything. Such as debt, promise contracts, free attorney and ... (Safai, ibid, p. 33). 
Some Iranian lawyers believe that the division of contracts into a unilateral and bilateral in Iranian law is redundant: "The division was created based on the idea that the effect of the contract is limited to creating commitment and in possessory and permission contracts commitment is an unclear issue. It is therefore incomplete and misleading and should be ignored. In addition, the division of contracts into "reciprocal" and "free" has no practical benefits; because, in our legal system any reciprocal contract has a mutual commitment and any contract in which there are two commitments is a reciprocal one. Also, free contract is in compliance with the unilateral contract. The concept of the reciprocal contract and free contract in the France law is not consistent with ours; so we don't need to divide the contracts like them. (Katouzian, 1995, p. 123).

Katouzian says: "Thus, it is better not to divide the contracts traditionally into free and reciprocal contracts but to replace them with bilateral and unilateral division; the division that does not have practical benefit is better to be neglected". (Ibid., P. 141).

One of the lawyers while accepting this division of rights, believes that it has advantages, for example the Civil Code, including Article 362 and 390 and 391 (guarantee of perception) and a couple of others, are the application of this division (Amir Ghaemmaghami, 1999, p. 70). Also it has been said that although often reciprocal contracts are bilateral and free contracts are unilateral, some contracts like deposit and loan contracts are both free and at the same time bilateral. Bill is not a condition for the validity of contracts and they result in the offer and acceptance, depositor and loan giver commit to give a property to the other party and the other party agrees to give that same thing to them (Safai, ibid, p. 36).

In the case of unilaterality or bilaterality of license contract, it must be said that the deal is mainly reciprocal and rarely without any consideration for the license of the intellectual property to other people. But, anyway, as we have said, the license contract may be divided into reciprocal and free. (Staines et al, ibid, p. 99). In the case of reciprocal licenses, which are often concluded in this way, there is no doubt that the mentioned contracts are bilateral; the license giver is committed to give the intellectual property of the subject of the contract the license receiver is committed to pay royalties.

But the free license, has the possibility of being concluded and at least the theoretical possibility is not ruled out; a distinction must be made between registered intellectual property licenses and not registered ones. That is, the registered license of intellectual property such as patents and trademarks indicates different conditions; the non-utilization of the property within the due date of law gives the nullity right to each beneficiary and in some countries such as the UK any beneficiary can request for compulsory license; therefore, even if the contract is free, receiving a the license receiver is still committed to the exploitation of the subject matter and the result of these agreements will be bilateral.

As for intellectual property, including technical knowledge, which are not registered, the license receiver has obligation to exploited, unless otherwise is stated in the contract. Non-utilization of the property does not force them to seek invalidation or compulsory license; Because, a key feature of this property, is its confidentiality and other people, presumably, are not informed about the details of their claim.

What was said in the free license, is consistent and aligned with the lawyers who believe that the division of contracts into a promissory and bilateral, is necessary.

\subsubsection{Formal}

Permission contracts or as some writers refer to it intent contracts (Shahid ibid, p. 82), are contracts which are concluded according to the will of the parties, on condition that there is some kind of benefit, and the implementation of these contracts does not require any formalities, such as the use of certain terms. Formal contract is an agreement with certain formalities such as setting official documents, and the will of the parties does not suffice; will shall be expressed in a certain form in the formal contract. (Safai, ibid, p. 41). In Iranian law, the contracts are primarily permission contracts, even in the case of real estate transactions that are required to be registered by law, some lawyers believe that the formal registration is not the only requirement (Shahid, ibid, p. 118). In contrast, another group of professors believe that the registration of such transactions is necessary. (Katouzian, 1990, p. 368). The first group believe that the provisions of the Real Estate Registration law does not state that the lack of a formal document can lead to the invalidity of the transaction. And Article 22 of this law, says the person who is the owner of a property and the property is registered in his name is considered the real owner by the government, and the judicial procedures also tend to not reject a claim based on normal document in such transactions. (Safai, ibid, p. 43).

We now turn to the main question that is the license contract a permission contract or a form one? In response to this question some distinctions must be made between the registered and unregistered intellectual properties; i.e. in the former case the contract is formal and in the latter case the contract is permission. Some articles of the patents registered laws have necessitated any transaction relating to patent or trademark to be registered, if they are not registered, they 
are not valid for third parties.

Another question is that; what is the guarantee of non-registration of registered intellectual property license, in Iran law? Is the contract in this case false or valid, if the called provides valid reasons the contract is valid, or relations between the parties that must be distinguished? If we consider the "law of patents, industrial designs and trademarks" of Iran (Especially Article 48 and 50) we may confirm that that the transactions will not be valid fort third parties, but there is no problem in relations between the parties. But this view is objected that the validity of a contract could not be parsed and validated against the parties in our law. In other words, relative nullity is not accepted in our law.

\subsection{The nature of the license contract}

In this section we analyze the nature of the license contract by comparing it with some specific contracts and the usufruct in Iran's civil code. We also have examined the comparative discussion.

\subsubsection{License and lease}

\subsubsection{Iranian law}

As we have seen License is a promissory contract, so to check its compliance with the lease contract we have to describe it through the promissory contract? In this regard, there is no consensus among the authors of the Iranian civil rights. Some authors have described the lease as a promissory contract. According to them the definition of lease in Article 466 of the Civil Code of Iran is criticized because it does not regard the obligations of the contract. Also they stress that the acquisition of benefits is misleading and distracts the mind from the obligations regarding the lease and guarantee of benefit. The author believes that the main obligation of the landlord in the lease contract, is to surrender the lease and guarantee the benefit of tenants. (Jafari Langroodi, 1996, pp. 33-31), but some people disagree that the possessory nature of the lease believing that this feature is derived Imamieh jurisprudence; in the Roman law, the lease contract is a promissory contract and it is reflected in the French law2; although the new law incline to the possessory nature of the lease. Though the possession of the lease contract is not right when interpreting some of its works, it cannot be easily considered among the promissory contracts under the influence of Article 1709 of the French law and public opinion of some of the jurists. (Katouzian, 1997, p. 348).

Can License be considered as a kind of lease?

Some writers believe that, renting the immaterial property is acceptable and intellectual property is immaterial. Having analyzed the benefits of the possession and the transfer of ownership rights, they believe the right that a person has in the result of the invention is similar to the lease. According to them, literary and industrial owner use his right as a lease, i.e., maintaining his ownership, he can give his invention to someone for a particular amount of time and get paid for this. From this perspective, civil code has accepted the renting in this sense, thus, the leasing of intellectual property is acceptable; because man cannot be considered rental, but the subject of rent, labor and human service can be. In this case, what difference does it make that wheather the material activity of a man is leased or his mental activity? Finally, it is concluded that "the obstacles of the sale or lease are difficult to legally and therefore the legislator has called it "transfer", but it seems that the difficulty of this accession is lower than rent. "(Ibid., Pp. 312 and 311).

Having the assumption that a License is a lease, we may conclude that the license receiver can in principle give sub-License, while this is vice versa in the licensing; i.e. License receiver cannot give sub-Licenses unless it is mentioned in the contract. Another result which is obtained through this consideration is that, in Iran law, the contract should be exclusive, and other types of non-exclusive (simple) or sole are not accepted in this situation. In this case the subject of the contract is possessed by License recipient and the License holder cannot give it to third parties, unless the possession mechanism of license holder and recipient is predicted which is highly unlikely in the time of signing the contract. ((Dashti, 2004, pp. 72, 73) Based on these considerations, License cannot be regarded as a kind of lease.

\subsubsection{Comparative Law}

The nature of License agreement are not clarifies in the industrial property laws of most countries; only the ability to

${ }^{2} \mathrm{~A}$ contract cannot be modified or terminated by the landlord before the end of the term, unless he uses a specific clauses, the "clause résolutoire". This clause can only be applied if the tenant does not pay the rent or if he hasn't taken an insurance (katouzian 1997, $p$. 379). 
transfer ownership or right to use the trademark, patent or technical knowledge are pointed out. In French law "Cod de la Propriete Industrielle " a few of the contracts are allocated to the use of industrial property; it is mentioned in the law that the right to use the property can be transferred to another. To address the issues that are related to License agreement the judges of this country use the Civil Code provisions relating to the lease contract, particularly Article 1708 of the Civil Code (Shams, ibid, p. 178) in Quebec, Canada, which is influenced by French law, the contract is subject to the lease contract. (Dashti, ibid, p. 72).the similar condition is observed in Egypt. (Ansari, 1995, p. 94). In Mexico due to the fact that the "federal trade law" of the country there areas no special provisions in the license agreement, the contract is anonymous (unknown) (Staines ${ }^{3} \mathrm{et}$ al., 2002, p. 99). Also in Switzerland and common law countries, this agreement also is considered a free and independent contract. (Ansari, ibid., P. 105). But in international trade law, since the contract is subject to the principle of contractual freedom, rights and obligations of both parties (in detail) is predicted, otherwise, it is obvious that if the parties have specific law governing contract the same law would govern the rights and obligations and their claims; for example, in French law, the judge of this country in the context of the provisions of the Civil Code extends the lease contract to the license agreements, or if we are considering one of the common law countries, we will realize that a license is an independent contract; rule of the common law will help the parties' will to judge (Ref: Ansari, ibid., Pp. $93,94)$. But if the law is not specified or for any reason cannot be applicable, such as viloation of e or fraud to the law, made, it is natural that the court would apply conflict rules in the determination of the law.

\subsubsection{License and the contract of sale}

At first glance it may seem that such a comparison and analogy with the contract of sale and the license agreement is incorrect; because, in license contract the permit to use the subject of the contract is given to others, while in a contract of sale, the subject is transferred to another. But we realize that the two contracts are not dissimilar, in many cases, patent or trademark licenses are exclusive and depend on the life of the Patent and Trademark Sheets. Considering the same technical knowledge, we may state that when the license recipient become aware of the secrets and details of the contract, he can no longer be compelled to forget so the subject of the license is transferred to him. In addition, many of the license contracts are exclusive and it's stated in them that that other entities, including the license holder, are not entitled to exploit the subject of the contract. In the many resources and examples of so-called contracts for the purchase or sale of license instead of "license receiver", the term buyer is used. Council of Ministers of the Islamic Republic of Iran has used the phrase in one of its decisions ${ }^{4}$.

\subsubsection{The Iranian law}

As we know, the subject of the license agreement, is the intellectual and industrial ownership. After confirming the compliance of the license contract and the contract of purchase, in Iran's rights (as well as comparative law), we have to check whether this property can be the subject of sale (the object of sale)?

To answer this question, it is better to consider the sale of intellectual property in the Imamieh jurisprudence. It is stated in Imamieh jurisprudence that the sold good shall be a material property and interest, right or practice cannot be sold.

For example, we consider a number of great jurists' decision on this matter. First, we start from the words of one of the contemporary jurists: "Apparently there is no doubt in conditioning the sold good; the possession of sold goods for common people is obvious." (Khoei, 1412 AH., P. 307)5. Also, one of the scholars in this field, says: "sale contract, as it is quoted in Mesbah Almnyr, is the exchange of property with other property; the exchange should be the objective; therefore, the transaction does not conclude the non-profit deals... "(Ansari, 2003, p. 7). One of the jurists also says: "Moreover, no disagreement on the fact that the sold good should be objective and thus scholars believe that the sale should exclusively transport objects such as the fact that the lease is for the transfer of benefit." (Najafi, 1996, p. 208) ${ }^{6}$. What has been stated above is the famous word of jurists, but in the words of some scholars and even some incoming news, so-called sold good is used to refer to the transfer of property, including the selling of services the right to reside in

\footnotetext{
${ }^{3}$ Article 3 of Implementing Regulations:Admission of foreign investment, based on fippa and the criteria set forth in these regulations, may be carried out within the framework of the following methods. The table of investment methods, features and facilities available under fippa shall be prepared and published by the ministry of economic affairs and finance

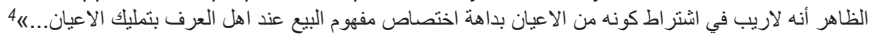

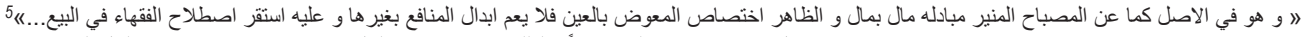

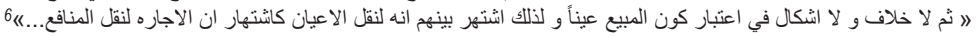


the home. (Ansari, 2003, pp. 6, 7)7. The difference between the famous resolutions (not to permit the sale of nonobjective materials) and the other one (the permission to sell the nonobjective material) is also explained: "... apparently the opposite interpretation by a negligence is accepted and interpreted as the transfer of some objects like fruit on the tree... "(ibid., p. 6) ${ }^{8}$. According to what was said, transfer of immaterial property cannot be a form of sales from the perspective of Shi'a jurists; because they consider sale exclusively in the transmission of material property rather than immaterial.

Now we examine the possibility of selling immaterial property in the Iranian civil code. Some lawyers not only do not believe in the objectivity of the sold good but state that legislators in several laws after 1928 (adoption of the first volume of the Civil Code) have abrogated the definition of the sale in Article 338 of the Civil Code and have violated it. They then defined their proposed definition of sale contract. (Jafari Langroodi, ibid, p. 462) .

Some lawyers recognizing the concept of the sale of property believe that in the selling of external objects, the object is not transferred but the credit relationship between the seller and buyer; what is called as property or right, are not materialized and external. They critically state that why the private ownership can be sold but the ownership of copyrights and goodwill can't be sold,; these issues are immaterial and the property cannot be sold and they should be transferred in accordance with the general rules? They believe that the benefit of considering immaterial intellectual property in Sales is the unity and integrity of the coagulation procedures, rules, and works. After a few examples on the development of legislation and liberation from the sale defined in Article 338 of the Civil Code, in the context of the sale of shares in trading as well as sales of goodwill and copyright, the author finally conceded the point that there are obstacles in the law of copyrights and patents to the sale and amendments to these transitions are easier when accepting the transfer to the lease. (Katouzian, 1997, pp. 312-305). Another lawyer believes that intellectual property can be considered an objective property because, although the property is different in terms of physical characteristics from a common objective property, but in contrast they cannot be considered as benefit, right or action of contract because benefit is derived from the wealth produced by others and is not independent, and also right is due to the dependence on the property right or obligation of others' property indirectly and lacks independence. Obviously, we cannot take the intellectual property as actions, however, a computerized software, for example, has independency and cannot be made the property of others; hence, this property can be the subject of sale. According to the author, the reproducibility of intellectual property such as software does not result in the amplified version of the original version be taken as the interests, but all of these versions compared to each other are fungible. (Shahidi, 2003, pp. 17-15)

From the above, it can be concluded that the transfer of intellectual property from the perspective of Shi'a jurists cannot be regarded as sales because the properties are not objective, while according to them, the issue of sale should be objective. This view is reflected in civil code of Iran. But legal doctrine of Iran tend to the contracts to be considered sale.

\subsubsection{Comparative rights}

In comparative discussion, first the situation of sale of intellectual property in the British's sale of goods act is investigated. ${ }^{10}$

According to this definition the subject of the sale contract is the good and whether it is considered intellectual property or not. In Part VI , Section 61( 1 ) of this act the goods is defined as: ": " Goods includes all personal chattels other than things in action and money ..."." The meaning of money is clear, what about the first term 'things in action'?

One of the authors of English law in response to our question states that "personal chatt" is versus "real property" and personal chatt, in turn, are divided into two categories: One of them is the intellectual property or rights obtained through litigation and the other one is the legal enforceable seizure of property (tangible or material possessions); only the latter is placed in the definition of the law having with these qualities: tangible, transferable and visible, can be removed from the capture and instances of it, such as: animals, furniture, grain, clothes and whatever that can be moved easily. «Things in action» cover cases such as stocks and other securities, demand, bills and other negotiable

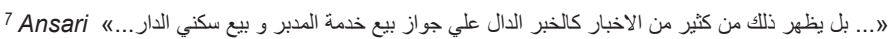

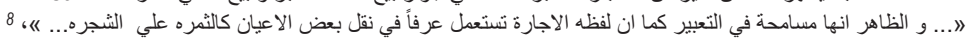

${ }_{9}$ Their definition reads: "Sale of the assets of each of the parties entering into two swap balancing of the financial flow is inverted. "Also, for more information see: the proposal to amend the civil law, pp. 265 and 264

10 Sale of Goods Act , 1979, Part II, Section 2(1) : "A Contract of sale of goods is a contract by which the seller transfers or agrees to transfer the property in goods to the buyer for a money consideration , called the price."
} 
instruments, patents, copyright, trademark and other intangible assets as well as other intellectual properties that the law does not recognize them as technical knowledge; these cases are the legal definition of foreign goods. (Benjamin, 1987, p. 63, quoting Haji Azizi, 1993, pp. 45-43). According to the analysis, goods' definition, deals not include intellectual property, even if they are in protection of the law, such as patents and trademark. There is no doubt that the subject of the technical knowledge is not included in the definition, because technical knowledge is a part of intellectual property and is protected by the law.

In the American law U.C.C , Art . 2 - 105 (1), goods is defined as: " Goods means all things (including manufactured goods) which are movable at the time of identification to the contract of sale other than the money in which the price is paid, investment securities and things in actions ". As we can see the intellectual properties are clearly excluded from the definition of goods.

But to complete the comparative discussion, it is better to consider the sale of intellectual property in the "Convention on the International Sale of Goods of 1980". The Convention does not define the goods, but has excluded the selling of some properties. Convention has noted stocks, bonds, negotiable instruments and money in Article 2 (4). One of the authors of the law in the UK, describes the possibility of including the Convention on all tangible property and materials, but he is doubtful on its application on computerized software's sales; we know that the computerized software are considered as intellectual property ( spiritual) (Bridge, 1999, pp. 47, 48).

\subsubsection{License and the entrustment of usufruct}

According to Article 40 of the Civil Code, the Usufruct is the right whereby that person can use the other properties which have other owners to do not have any owner. Usufruct is one of the branches and levels of personal property that is awarded by a contract, so in usufruct right, there are always two owners: one the benefited that has the right to benefit from the objectives and the other is the owner that by the contract shares a large amount of the rights (Katouzian, 2002, pp. 207, 208). The source of usufruct contract, except in the case of endowment which is subject to certain conditions, has particular title in civil law and its accuracy is determined according to Article 10 of the Civil Code and the general rules of contract. (Ibid., P. 283).

Since the license contract, "usufruct" and exploitation of intellectual property and industrial property is granted to license receptor, the essence and form of this contract is formed like that (Cornish 1989, p. 179).

Some author of civil code do not accept the intellectual contracts like copyright and patents, to be usufruct contracts. According to them, "usufruct right is objective; it must be about physical objects. Usufruct of religion and moral rights must be examined in accordance with Article 10 of the Civil Code ... "(Katouzian, ibid., P. 283).

It seems that the author is right, despite the similarities between these two institutions their distinction is so bold that they cannot be placed in a same category. By comparison, the "creator usufruct contract" in Iranian civil law "license agreement" can include:

Transfer of usufruct in most cases is free and that is why the authors believe that it is an irreplaceable contract, mortmain contract is also free and is especially for the poor and charity, reciprocal conditions violate it. (Adl, 1994, p. 63). While the license agreement in principle is a reciprocal contract and can be of course free. (Staines ibid, p. 99).

In the transfer of usufruct, the exclusive right to use the property is transferred to a person other than the owner. While this is true only in the exclusiveness of the license. In the non-exclusive license (or plain), the license holder may also benefit from the contract or give third parties such permission (Cornish, a priori, p. 183).

The two sides' agreement is not sufficient for the usufruct; the rights of subject property must also be given to capture and bill of benefit and if one of the parties die during the implementation of the contract, the contract will become void (derived from Article 802 of the Civil Code). According to the Usufruct and mortmain it can be inferred that the only some properties can be the subject of such contracts; those that have physical and material objectivity, while the issue of intellectual property license contracts are not physical. In contracts related to the establishment of usufruct, no prediction is considered by the legislative procedures in any form, whether for citations between the parties or third parties but in patent license contract and other registered industrial properties, the due process is necessary to be recorded. In addition, the technical knowledge of the license agreement is written.

\section{Conclusion}

In this article, we defined the license agreement and stated that the essence of this contract and its requirements is to transfer industrial property. We also observed that license, often not independently but along with other institutions such 
as franchise, BOT or buyback is achieved. Patent, trademark and technical knowledge can be considered as the Industrial Property that are the subject of the license. In terms of the general categories, license contracts are promissory contracts, but, intellectual property, as the subject of these contracts have no physical existence to be owned by the license receiver; by signing these contracts a series of obligations are transferred to the parties. On the other hand registered intellectual property license, even in a free condition, are bilateral contracts because the non-utilization of their property is subject to invalidation or, in some countries, compulsory license is subject to the obligation to use patent or trademark in the responsibility of the recipient license. In the case of formality or permission of the contracts we have to consider a distinction in registered intellectual property license, such as patent or trademark on the one hand, and unregistered intellectual property, including technical knowledge on the other hand; the former is a formal contract because legal acts on this kind of property should be registered.

In response to the question: What is the nature of the contract license in Iran? We may say that these contracts are lease as is the case in France and Canada. In Iran, some lawyers believe, that the contracts whose issue is the transfer of ownership or right are better to be considered as lease. But the acceptance of this idea, at least in Iran, is difficult; if we assume that the license is a lease, then the receiver can give sub-licenses without the consent of the license, , while the license holder; This usually is not the case; i.e. the License receiver cannot grant sub-license unless it is stated in the contract. Another result obtained from considering License as a lease is that, in Iran, the contract be consisted of one type and exclusive; non-exclusive (simple) or sole contracts cannot be placed in this category. In this case the subject of the contract is possessed by License recipient and the License holder cannot give it to third parties, unless the possession mechanism of license holder and recipient is predicted which is highly unlikely in the time of signing the contract. Based on these considerations, License cannot be regarded as a kind of lease.

Another Assumption is that the License is a kind of usufruct, but this assumption is also faced with problems; transfer of usufruct is a concrete and objective contract. Establishment of usufruct in most cases is free while the royalty is a key element of License contract. In addition, License of intellectual property must be registered, but the establishment of usufruct, in principle, does not require certain formalities.

In the similarity of License and sale contracts, it was mentioned that in the sale contract and according to the Iranian civil code and popular opinion of Jurisprudence, the sold good must be objective but intellectual property have no physical objectivity. So license contracts are not like sale contracts. In terms of comparative law, sale of goods act of the UK and the US Trade unified intellectual property have been excluded the license contracts from the coverage of the goods' definition. Usually in the international License law, the contract parties determine and describe the laws of the (the nature of) contract.

Therefore, it can be concluded that License contract in Iranian law is subject to any specific contracts, but has its own special circumstances and consequences; it is an indefinite contract, subject to Article 10 of the Civil Code. Of course, it can be concluded that the general rules governing contracts, such as those in Article 190 of the Civil Code which are the basic elements of the deal, are applicable to this contract as well. However, on other subjects, if the contract is silent on a particular matter, the general principles of law and custom should be considered.

\section{References}

Schmitthoff, M Clive , international trade law, translated by Behrouz Akhlaqi et al. Tehran, Samt, 1998

Imami. Sayed Hasan, civil rights, vol. 1, Tehran, Islamiyah, published twenty-first, 2000

Amiri Qaem Maqami. Abdul Majeed, rights and obligations, c. 2, Tehran, Mizan, second edition, 2000

Ansari. Sheikh Morteza, Makasib: pleadings of Ayatollah's final lesson by fakhar Toosi, c. 10, Qom, Publishing House of Darol Hekmeh,2003

Ansari. Mehdi, international agreements, technology license, Quarterly

Haji Azizi Bijan. B. Transfer of technical information and comparative law of Iran (technology transfer), MAThesis, super visor Dr. Goudarz Jahromy, Shahid Beheshti University. School of Law, 1993

Habiba. Said, patent system in Iran after the adoption of the Agreement on Trade Related Aspects of Intellectual Property Rights, Faculty of Law and Political Sciences of Tehran University, No. 66, Winter 2004, pp. 183-1

Dashti. Vahid, introduction of technology transfer agreements based on License agreement, newsletter and technology rights, no. 11, June 2004, pp. 74-66

Jafari Langroodi. Mohammad Jafar, civil rights and trade Encyclopedia, vol. 1, Tehran, Mashal-e- Azadi, 1995

Dehkhoda. Ali Akbar, dictionaries, c. 12, Tehran University Press, first edition of the new period, 1994

Sharif. Navaz, transfer of technology and development, translation Rashid Aslani, Management and Planning Organization, Tehran, 1988

Shams. Abdul Hameed, trade marks and industrial property rights over Tehran, the, 2003

Shahidi. Mahdi, civil rights (6), Tehran, Majd, 2003 
Shahidi. Mahdi., form contracts and commitments, Tehran, Majd, second edition, 2001

Shiravi. AbdolHossein, BOT contracts and transfer; Qom, Qom Publications (Tehran University), 2005

Shiravi. AbdolHossein, various methods of mutual trade agreement, Journal of Law, College of Qom, Tehran University, Autumn and Winter 2004, pp .47-5

Safai. Seyed Hassan, civil rights, vol. 2, Tehran, rate, 2003

Adl. Mostafa, civil rights by Mohammad Reza Bandarchi, Qazvin, Bahr al Olum, 199

Katouzian. Nasser, property and ownership, Tehran, Mizan, 2002

Katouzian. Nasser, general rules of contracts, vol. 1, Tehran, Publishing Company, Third Edition, 1995

Katouzian. Nasser, certain contracts, vol. 1, Tehran, Publishing Company, Sixth Edition, 1997

Najafi. Seyed Mohammad Hassan, al-kalam fi Sharhe Sharayeh Islam, vol. 22, Tehran, Daralktab al, 1986

Nasiri. M., international trade rights in the current legal system of Iran, Tehran, Amir Kabir, 2004

Bridge. Michael,The International Sale of Goods، 1th ed, Oxford University Press, 1999

Campbell. Henry , Black's Law Dictionary, U.S.A, West Publishing Co, 6 th ed, 1990

Cornish .William, Intellectual property : patent. copy Right. Trade Marks and Allied Rights, 2th ed, London, Sweet and Maxwell, 1989

Curlley. Duncan, Intellectual prorerty licenses and Technology Transfer, chandos publication, 2004

Fewick and west's Intellectual property Group, paten Licensing for High Technology Companies, U.S.A. Fenwick publication, 2003, (20 p) available at : www.Fenwick.com/doc stor/publications/lp patent Licensing (pdf)

Hornby (A.S), Oxford Advanced Lerner`s Dictionary, London, Oxford University press, 6th ed, 2000

Meier. Lawrence, An Introdution to Intellectual property Licensing for Technology Companies.U.S.A,2004(22 p), available at : www.drm.com/newstand/publications/lp.Issues.facing. High.Tech.Companies.(pdf)

Nanayakkara Tammara, Negotioting Technology Licensing Agreements, Internatinal Trad Forum (the Magazine of International Trad center), April. 2004 ( P. 13 )

Staines . Alegandro and Others, Licensing Intellectual property In Mexico, The Comparitive Law Year Book of International Business, Vol. 24, Salzburg (Austria), 2002, ( pp. $97-123$ )

Unido, Manual on Technolgy Transfer Negotiation : A Refrence for Policy - Makers \& Practitioners on Technology Transfer, Vienna, 1996

Van Houtt . Hans, The law of International Trad, London, Sweet and Maxwell, 2th ed, 2002 